\title{
Indigenous people's education, career aspirations, choice and challenges among senior high school students in rural communities in Palawan
}

\author{
Andrea Josefa D. Perez ${ }^{a, 1}$, David R. Perez ${ }^{a, 2^{*}}$, Carolyn M. Illescas ${ }^{a, 3}$ \\ ${ }^{a}$ College of Education, Western Philippines University, Princesa City, Philippines \\ ${ }^{1}$ perezandreajosefa@gmail.com; ${ }^{2}$ daveperez2004@yahoo.com*; ${ }^{3}$ drp612312@gmail.com \\ * corresponding author
}

ARTICLE INFO

Received 2020-05-03

Revised 2020-11-23

Accepted 2021-01-29

Published 2021-04-07

Keywords

Indigenous people

Education

Career aspirations

Career choice

Challenges

\section{ABSTRACT}

The study was conducted to determine the Indigenous people's education, career aspirations, career choice, and challenges among senior high school students in rural communities in Palawan. Qualitative and quantitative methods were used in the study. Mean, frequency counts, percentages, T-test, and Pearson Moment Correlation were employed. Results revealed that most parents had ages 39-44 years old, female, high school level, farmers, and earned below 1,000. As for ethnicity, most of them belong to the Palawan tribe, had 3-4 children, and cash conditional transfer recipients. It also revealed that most of the learners had ages between 18-19 years old, female, Palawan, the first child in the family, enrolled under Technical Vocational and Livelihood, and traveled 5 kilometers from residence to school. As for the parents and learners' career aspirations, they have the same response to finish their studies and improve their living conditions. Parents and learners had a mutual understanding about the career choice of the learners. There is no significant relationship between the Parent's profile and the Career Choices of the learners. There is no significant relationship Between Parent-Respondents Profile and Career Aspirations of the Learners except in parents' age. There is no significant Relationship Between Learner-Respondents Profile and Career Aspirations except in age, sex, and track profile. There is no significant relationship between the parents' demographic profile and the educational challenges except in Parent's occupation, cash conditional transfer recipient, and some children. There is no significant relationship between the learner's demographic profile and the educational challenges except in distance from school, birth order, and sex. There is a significant difference between career aspirations among learners and their parents, while there is no significant difference between the career choice among indigenous learners and their parents and educational challenges among learners and parents.

This is an open access article under the CC-BY-SA license.

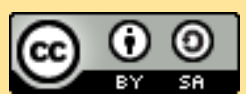

\section{Introduction}

Education is recognized as both a human right [1] and an indispensable means of realizing other human rights and fundamental freedoms. It is the gateway by which economically and socially marginalized peoples can lift themselves out of poverty and obtain the means to participate fully in their communities. In addition, education is defined as increasingly recognized as one of the best long-term financial and social investments countries can make. Appropriate education enables indigenous children and adult learners [2] to exercise and enjoy economic, social, and cultural rights. It also strengthens their ability to exercise their civil rights so they can influence political policy processes for enhanced protection of their human rights. Education is therefore a vital means for the 
enjoyment, maintenance and transmission of indigenous cultures, languages, traditions and traditional knowledge [3], as well as a vehicle for individual empowerment and agency [4]. Education is one of the six mandated areas of the United Nations Permanent Forum on Indigenous Issues and an area on which we have much to say. Indigenous communities face many challenges in education. We live in a world that is increasingly multicultural, and the traditional understanding of the content of curricula and ways of teaching, even for those states that are organized on the assumption that they are culturally homogenous (The United Nations Permanent Forum on Indigenous Issues) [5].

Education is a fundamental human right, as enshrined in the Universal Declaration of Human Rights and reaffirmed in the World Declaration on Education for All and The Dakar Framework for Action. The commitment of the international community to the provision of quality education to meet the basic learning needs of all children, youth, and adults of today's culturally and linguistically diverse societies is clearly expressed within these international normative instruments. The right of indigenous peoples to have access to education has often been mistakenly interpreted as meaning that indigenous peoples only want access to non-indigenous education. Yet indigenous peoples across the world are demanding educational provision that is both linguistically and culturally appropriate to their needs while not excluding them from broader access to national education systems. At the same time, education needs to be empowering and to draw from indigenous culture and wisdom [6]-[8]. The International Labour Organization (ILO) Convention 169 in 1989 defines the IP as "tribal people in independent countries whose social, cultural and economic conditions distinguish them from other sections of the national community, and whose status is regulated wholly or partially by their own customs or traditions or by special laws or regulations." It entails recognition of their presence, their historicity and cultural indelibility [9]-[11].

Stavenhagen has coined the term 'ethnocratic' for these kind of states, simply does not work anymore [12]. The world is more uncertain than ever before, as o bserved both by the World Commission on Cult ure and Development (the De Cuéllar Commission) and the International Commission on Education for the Twenty-First Century (the Delors Commission). Furthermore, indigenous peoples and minorities are largely ignored in most countries in both the design of curricula and the organization of teaching [13], [14]. In fact, in many countries the basic principles of multilingual and multicultural education as established by UNESCO have been barely implemented. And lastly, there is always the question of resources. We are poorest among the poor. Even in developed countries, indigenous communities are not able to offer their children adequate education and especially not an education that meets the aspirations of the peoples themselves. Over the years, UNESCO had vigorously campaigned for the welfare of indigenous people around the World. This was specifically highlighted during the 2007 UN General Assembly which created the UN Declaration on the rights of indigenous people (UNDRIPS) [15]. Most of the literature about Indigenous people (IP) focused on health, environmental issues, socioeconomic well-being, and few studies were related to education, especially in the Philippines.

The last decade has seen a wide spectrum of substantial efforts to raise the standard of work and life of the regions where most IP communities are found. Hence, one can only speculate about the causes of a disappointing share of ICCs/IPs in national development, manifested in their material poverty and low HDI rating. Obviously, public, and private initiatives for the socioeconomic development and nondiscrimination of ICCs/IPs must take place in the wider framework of policies embodied in IPRA and the government's development plans. Through this study, the researcher determined the career aspirations, career choice and challenges among Senior high school Students in selected rural communities in Palawan.

\section{Method}

Determine the demographic profile of the parents in terms of: Age, sex, hhighest educational attainment, occupation, monthly income, ethnicity, number of children, and conditional cash transfer recipient (CCT). Determine the profile of the indigenous Senior high students in terms of: Age, sex, grade level, track/stream, ethnicity, birth order, school, and distance of residence from school? Determine the career aspirations of IP parents and their senior high school students in terms of; Education, employment, and life goals. Determine the career choices of IP senior high school students, determine the educational challenges encountered by senior high school indigenous people's students in terms of, Learner factor, family factor, health factor, cultural factor, school factor, and socioeconomic factor. Determine the significant relationship between the respondents' demographic 
profile, and the career choices demographic profile of the parents and the career aspirations of Indigenous senior high school learners. Demographic profile of indigenous senior high school and their aspiration. The demographic profile of the Indigenous parents and the educational challenges encountered by the indigenous senior high school learners. The demographic profile of the learners and the educational challenges encountered by the indigenous peoples learners. Determine the significant difference between respondents', career aspiration, career choices, and educational challenges parents and learners.

\subsection{Research Design}

This study used qualitative and quantitative research methods [16]. qualitative method was used to describe the career choice, career aspirations and challenges of selected senior high school student belonged to indigenous peoples in Palawan. Qualitative data sources include interviews, focus group discussion (FGD), documents and texts, and the interviewee's impressions and reactions. Furthermore, quantitative design was also used in the conduct of this study. This research method consists of descriptive and correlational research. This method primarily focuses on describing the nature of demographic section. This method was used to obtain information concerning the demographic profile of the respondents as well as their career choice, career aspirations and challenges encountered. In addition, correlational research was utilized since it assessed the relationship of the demographic profile of the respondents to the career choice, career aspirations and challenges encountered. The respondents of the study were the enrolled Senior High Schools students and their parents who belonged to Indigenous peoples in the secondary schools in Palawan. Total enumeration was employed in the study considering the number of Indigenous Peoples learners in the Secondary Schools. Purposive sampling was used in the selection of IP parents and Senior High School learners as respondents. The researcher made questionnaire was used in this study. The researcher used two sets of survey questionnaires; one is for the parents-respondents and for the learner respondents.

\subsection{Data Collection}

The study utilized primary data sources using survey questionnaire (combination of closed-ended and open-ended questions which were pre-tested among IP students and parents who a part of the study was not. Prior to the distribution of the questionnaire, validation was made to determine the reliability of the questions provided in the instrument. The survey questionnaire was administered to the parents and learners who belong to Indigenous tribe. The purpose and direction on how to accomplish the questionnaire were explained by the researcher. The semi-structured interview questions were developed by the researcher with the assistance and guidance of research adviser.

\subsection{Treatment of Data}

This study used different statistical tools to analyze and interpret the data. The data were analyzed through descriptive measures such as mean, frequency counts, and percentages, Chi- square, Pearson Product Moment Correlation, T-test, and ANOVA test. To assess and describe the career choice, career aspirations and challenges that belong to Indigenous Peoples, the frequency and mean were computed. To test the relationship, the relationship between demographic profile of the respondents, the career aspiration and career choice, Chi-square was used. T-test and Pearson Product Moment Correlation were used to test the demographic profile and educational challenges. Meanwhile, Anova test was used to get the difference between career aspiration, career choice and educational challenges of the respondents.

\section{Results and Discussion}

\subsection{Demographic Profile of Parent Respondents}

Table 1 shows the demographic profile of parent respondents as to their age, sex, educational attainment, occupation, monthly income, ethnicity, number of children and cash conditional transfer recipient. It can be seen from the table that of the six (6) ranges listed for age, of indigenous Senior high school parents were mostly at the range of 39-44 with the frequency of 21 or 36.8 percent. This was followed by those under the range of 45-50, 15 or 26.3 percent; 51-56 with 8 respondents or 14.0 percent; 33-38 with 7 respondents or 12.3 percent; 57-62 with 5 respondents or 8.8 percent; and 6368 with 1 respondent or 1.8 percent. With regards to sex majority are female with a frequency of 50 0r 87.71 percent and the rest were male with 7 or 12.3 percent. As to educational attainment, most of 
them were at high school level (26 or $45.6 \%)$. The rest are elementary graduate (17 or $29.8 \%$ ); elementary level (10 or $17.5 \%)$; and college level (4 or $7.0 \%)$. Farming was the primary occupation of the parents ( 29 or 50.9$)$; some were vendor (12 or $21.1 \%)$; others were laborers (10 or $17.5 \%)$; fisher (4 or 7.10\%); while the least were employee and driver with the same frequency of 1 or 1.8 percent.

As for monthly income, parents earned below 1,000 (30 or 52.6\%); others earned 1,000- 9,999 (22 or $38.6 \%$ ) while the rest earned $10,000-19,999$ (5 or $8.8 \%)$. For the ethnicity of the parents 32 or 56.1 are Palaw'an while 25 or $43.9 \%$ were Molbog. Of the 5 (five) number of children order, they were mostly 3-4 number of children with the frequency of 20 or 35.1 percent. Some falls under 5-6 number of children with the frequency of 18 or 31.6 percent. Others were under 1-2 and 7-8 number of children with the same frequency of 8 or 14.0 percent; and 9-10 number of children with frequency of 3 or 5.3 percent. Of the cash conditional transfer recipient, most were recipient with frequency of 34 or 59.6; and the rest were not recipient with frequency of 23 or 40.4 percent.

Table 1. Demographic profile of the parents of Indigenous senior high school in Bataraza, Palawan

\begin{tabular}{|c|c|c|}
\hline Characteristics & Frequency & Percentages \\
\hline \multicolumn{3}{|l|}{ Age } \\
\hline $33-38$ & 7 & 12.3 \\
\hline $39-44$ & 21 & 36.8 \\
\hline $45-50$ & 15 & 26.3 \\
\hline $51-56$ & 8 & 14.0 \\
\hline $57-62$ & 5 & 8.8 \\
\hline $63-68$ & 1 & 1.8 \\
\hline \multicolumn{3}{|l|}{ Gender } \\
\hline Female & 50 & 87.71 \\
\hline Male & 7 & 12.3 \\
\hline \multicolumn{3}{|l|}{ Educational Attainment } \\
\hline Elementary Level & 10 & 17.5 \\
\hline Elementary Graduate & 17 & 29.8 \\
\hline High School Level & 26 & 45.6 \\
\hline College Level & 4 & 7.0 \\
\hline \multicolumn{3}{|l|}{ Occupation } \\
\hline Laborer & 10 & 17.5 \\
\hline Farmer & 29 & 50.9 \\
\hline Driver & 1 & 1.8 \\
\hline Vendor & 12 & 21.1 \\
\hline Employee & 1 & 1.8 \\
\hline Fisher & 4 & 7.0 \\
\hline \multicolumn{3}{|l|}{ Monthly Income } \\
\hline$<1,000$ & 30 & 30 \\
\hline $1,000-9,999$ & 52.6 & 52.6 \\
\hline $10,000-19,999$ & 22 & 22 \\
\hline \multicolumn{3}{|l|}{ Ethnicity } \\
\hline Palaw'an & 32 & 32 \\
\hline Molbog & 56.1 & 56.1 \\
\hline \multicolumn{3}{|l|}{ Number of Children } \\
\hline $1-2$ & 8 & 8 \\
\hline $3-4$ & 14.0 & 14.0 \\
\hline $5-6$ & 20 & 20 \\
\hline $7-8$ & 35.1 & 35.1 \\
\hline 10 & 18 & 18 \\
\hline \multicolumn{3}{|l|}{ CCT Recipient } \\
\hline Not recipient & 23 & 23 \\
\hline Recipient & 40.4 & 40.4 \\
\hline
\end{tabular}

\subsection{Demographic Profile of Learner Respondents}

Table 2 shows the demographic profile of the Learner respondents as to their age, gender, grade level, track, ethnicity, birth order and distance from school. It can be seen from the table that the average age of the learners was at the range of 18 to 19 years old with a frequency of 29 or 50.9 percent, 18 or 31.6 percent belonged to the age between 16-17 years old while 10 or 17.5 percent belonged to the age between 20 and above. This implies that their ages are in proportion to their grade 
level. With regards to their gender, most (36 or $63.2 \%$ ) of the learner respondents are female, while 21 or 36.8 percent of them are male. As to their grade level, 57 or 100 percent were grade 12 students. As to their track, 36 or 62.2 percent were enrolled in TVL while 21 or 36.8 percent were enrolled in Academic Track. For the ethnicity of the learners 32 or 56.1 percent were Palaw'an while 25 or 43.9 percent belonged to Molbog tribe. Of the ten (10) birth order, they are mostly $1^{\text {st }}$ child with the frequency of 14 or 25.6 percent. The rest falls under $2^{\text {nd }}$ and $3^{\text {rd }}$ child with the same frequency of 13 or 22.8 percent; $4^{\text {th }}$ child with frequency of 6 or 10.5 percent; $7^{\text {th }}$ child with frequency of 4 or 7.0 percent; and $8^{\text {th }}$ and $10^{\text {th }}$ child with the same frequency of 1 or 1.8 percent. As to distance from school, most learners ( 25 or $43.9 \%$ ) travel 5 kilometers above; others travel between 1 kilometer ( 9 or $15.8 \%$ ); some travel between 3 kilometers ( 8 or 14.05; 4 kilometers 7 or $12.3 \%$ ); 2 kilometers (6 or 10.5\%); and below 1 kilometer ( 2 or $3.5 \%$ ). The results imply that most of the learners travelled more than 5 kilometers to reach the school, but they strived to attend school in spite of the distance they experienced.

Table 2. Learner-Respondents Profile

\begin{tabular}{|c|c|c|}
\hline Characteristics & Frequency & Percentages \\
\hline \multicolumn{3}{|l|}{ Age } \\
\hline $16-17$ & 18 & 18 \\
\hline $18-19$ & 20 & 31.6 \\
\hline 20> & 10 & 29 \\
\hline \multicolumn{3}{|l|}{ Sex } \\
\hline Male & 21 & 36.8 \\
\hline Female & 36 & 63.2 \\
\hline \multicolumn{3}{|l|}{ Grade Level } \\
\hline Grade 12 & 57 & 100 \\
\hline \multicolumn{3}{|l|}{ Track } \\
\hline TVL & 36 & 63.2 \\
\hline Academic & 21 & 36.8 \\
\hline \multicolumn{3}{|l|}{ Ethnicity } \\
\hline Palawan & 32 & 56.1 \\
\hline Molbog & 25 & 43.9 \\
\hline \multicolumn{3}{|l|}{ Order of birth } \\
\hline $1 \mathrm{st}$ & 14 & 24.6 \\
\hline 2nd & 13 & 22.8 \\
\hline $3 \mathrm{rd}$ & 13 & 22.8 \\
\hline 4th & 6 & 10.5 \\
\hline 5 th & 2 & 3.5 \\
\hline $6^{\text {th }}$ & 3 & 5.3 \\
\hline $7^{\text {th }}$ & 4 & 7.0 \\
\hline $8^{\text {th }}$ & 1 & 1.8 \\
\hline $10^{\mathrm{th}}$ & 1 & 1.8 \\
\hline \multicolumn{3}{|l|}{ Distance from School } \\
\hline$<1 \mathrm{~km}$ & 2 & 15.8 \\
\hline $1 \mathrm{~km}-1.9 \mathrm{~km}$ & 9 & 10.5 \\
\hline $2 \mathrm{~km}-2.9 \mathrm{~km}$ & 6 & 14.0 \\
\hline $3 \mathrm{~km}-3.9 \mathrm{~km}$ & 8 & 12.3 \\
\hline $4 \mathrm{~km}-4.9 \mathrm{~km}$ & 7 & 15.8 \\
\hline $5 \mathrm{~km}>$ & 25 & 3.9 \\
\hline
\end{tabular}

Table 3 showed that parents gave the highest rating on the statement: "encourage them to go to school every day" with a mean rating of 4.88 , describe as always while the least was the statement "give them awards/rewards to be motivated to go to school" with a mean 1.98, described as seldom and with overall mean of 3.90 described as often. The results imply that students are encouraged or motivated to learn and go to school. Parents encouraged their children to go to school. 
Table 3. Educational Challenges Encountered by the Parents in terms of Learners Factor

\begin{tabular}{|c|c|c|}
\hline Statement & Mean Rating & Descriptive Rating \\
\hline Encourage them to go to school every day. & 4.88 & Always \\
\hline $\begin{array}{l}\text { Give them awards/rewards to be motivated to go } \\
\text { to school. }\end{array}$ & 1.98 & Seldom \\
\hline They find it hard to understand their lesson. & 2.56 & Occasionally \\
\hline They can easily remember their past lesson. & 3.96 & Often \\
\hline $\begin{array}{l}\text { They study hard to improve their personality and } \\
\text { improve their life. }\end{array}$ & 4.75 & Always \\
\hline $\begin{array}{l}\text { They prefer to study their lesson than going out } \\
\text { with friends. }\end{array}$ & 3.95 & Often \\
\hline $\begin{array}{l}\text { They still want to go to school even without money } \\
\text { or "baon". }\end{array}$ & 4.26 & Often \\
\hline They can comprehend instructions easily. & 4.02 & Often \\
\hline $\begin{array}{l}\text { They can exhibit excellence even without } \\
\text { motivation. }\end{array}$ & 4.04 & Often \\
\hline Motivates them to finish their studies. & 4.63 & Always \\
\hline Overall Mean & 3.90 & Often \\
\hline
\end{tabular}

Table 4 showed that in terms of family factor, the statement "I encourage them to go to school every day" had the highest rating with a mean of 4.37 , described as often, while the least was the statement "I take good care of them alone" with a mean of 1.19 described as never; the overall mean rating is 2.73 described as occasionally. The results imply that parents encouraged their children to school.

Table 4. Educational Challenges Encountered by Parents in terms of Family Factor

\begin{tabular}{lcc}
\multicolumn{1}{c}{ Statement } & Mean Rating & Descriptive Rating \\
\hline $\begin{array}{l}\text { Support them in doing their school projects. } \\
\text { Let them take care their younger siblings even in } \\
\text { school days. }\end{array}$ & 3.63 & $\begin{array}{c}\text { Often } \\
\text { Seldom }\end{array}$ \\
$\begin{array}{l}\text { Punish them when they commit mistakes despite } \\
\text { difficulties. }\end{array}$ & 2.72 & Occasionally \\
$\begin{array}{l}\text { Encourage them to go to school every day. } \\
\text { Let them help in working to earn money for family } \\
\text { expenses. }\end{array}$ & 4.37 & Often \\
$\begin{array}{l}\text { Let them do our household chores Even in school } \\
\text { days. }\end{array}$ & 1.82 & Seldom \\
$\begin{array}{l}\text { Encourage them to study their lesson after school. } \\
\begin{array}{l}\text { Correct their mistakes by explaining and telling } \\
\text { the best things to do. }\end{array}\end{array}$ & 1.86 & Seldom \\
$\begin{array}{l}\text { Explain them that we do not have permanent } \\
\text { home. }\end{array}$ & 4.23 & Often \\
$\begin{array}{l}\text { Take good care of them alone. } \\
\quad \text { Overall Mean }\end{array}$ & 4.07 & Often \\
\end{tabular}

Table 5 showed that in terms of health factor, the statement "we ate meals three times a day" with a mean of 4.82 described as always, while the least was the statement "My son/daughter has vices like smoking cigarette and drinking liquor" with a mean of 1.05 describes as never; with an overall mean of 2.90 described as occasionally. The results implied that despite poverty parents provide food for their family and ensure the health and safety especially of their children. Many parents included fruit and vegetables to different levels and were encouraged to provide healthy food for their children and suggest that the diets of these children could be improved through adequate support and information. There has been evidence that many parents' diets have also improved when they strive to improve their children's diets. The results of this in depth, small-scale study highlighted several problems in early years with respect to local and national nutrition policy and practice. 
Table 5. Educational Challenges Encountered by Parents in terms of Health Factor

\begin{tabular}{lcc}
\multicolumn{1}{c}{ Statement } & Mean Rating & Descriptive Rating \\
\hline Bring them to the hospital when they are sick. & 3.63 & Often \\
Prepare nutritious and healthy foods. & 4.17 & Often \\
Have clean hygiene facilities. & 4.58 & Always \\
They have vices like smoking cigarette and drinking & 1.05 & Never \\
liquor. & & \\
We ate meals three times a day. & 4.82 & Always \\
They belong to those malnourished. & 1.32 & Never \\
Have vices like smoking cigarette and drinking liquor. & 1.40 & Never \\
We have our own comfort room. & 4.72 & Always \\
They have health problem. & 1.42 & Never \\
We have poor housing sanitation & 1.91 & Never \\
$\quad$ Overall Mean & $\mathbf{2 . 9 0}$ & Occasionally \\
\hline
\end{tabular}

\subsection{Educational challenges encountered by the parents in terms of cultural factor}

Table 6 shows that in terms of cultural factor, the statement "proud to use our native language" had the highest rating with a mean of 4.82, described as always; while the least was the statement "Tell them stories about our tribe" with a mean of 3.07, described as often, the overall mean is 4.19 which is described as often. The results imply that indigenous people are still proud of their culture in spite of the modern times.

Table 6. Educational Challenges Encountered by Parents in terms of Cultural Factor

\begin{tabular}{lcc}
\multicolumn{1}{c}{ Statement } & Mean Rating & Descriptive Rating \\
\hline Proud to use our native language. & 4.82 & Always \\
Proud to say that we belong to our tribe. & 4.77 & Always \\
Let them join in the school activity showing our tradition. & 4.63 & Always \\
Their school respects our beliefs and traditions. & 4.45 & Often \\
Their teachers use indigenized teaching materials. & 4.23 & Often \\
Tell them stories about our tribe. & 3.07 & Often \\
Teach them our beliefs and traditions & 4.21 & Often \\
Allow them to join in the ritual we conducted in our tribe. & 3.98 & Often \\
Wear tribal clothes. & 3.54 & Often \\
Obey and respect oral laws of the elder. & 4.16 & Often \\
$\quad$ Overall Mean & $\mathbf{4 . 1 9}$ & Often \\
\hline
\end{tabular}

\subsection{Educational challenges encountered by the parents in terms of school factor}

Table 7 shows that in terms of school factor, the statement "the school respects our culture" had the highest rating with a mean of 4.86, described as always, while the least was the statement "teacher uses our native language in teaching" with a mean of 1.37, described as never, the overall mean is 3.97 which is described as often. The study implies that school respects the cultural identity of the learners that multicultural classroom is now the norm rather the exception.

Table 7. Educational Challenges Encountered by Parents in terms of School Factor

\begin{tabular}{lcc}
\multicolumn{1}{c}{ Statement } & $\begin{array}{c}\text { Mean } \\
\text { Rating }\end{array}$ & $\begin{array}{c}\text { Descriptive } \\
\text { Rating }\end{array}$ \\
\hline Teacher uses our native language in teaching. & 1.37 & Never \\
Teacher uses indigenized Materials in teaching. & 2.61 & $\begin{array}{c}\text { Occasionally } \\
\text { Always }\end{array}$ \\
Teachers treat them as a unique individual. & 4.77 & Always \\
School respects individual differences & 4.84 & Always \\
Teachers value our beliefs traditions & 4.82 & Often \\
Their school is free from racial discrimination. & 4.17 & Always \\
The school respects our culture. & 4.86 & Always \\
The school innovates program that help us to sustain our progress. & 4.82 & Often \\
Teachers are friendly and supportive. & 4.47 & Occasionally \\
They find it hard to understand their lesson due to lack of supportive materials. & 2.93 & Often
\end{tabular}

\subsection{Educational challenges encountered by the parents in terms of socio-economic factor}

Table 8 showed that in terms of socio-economic factor, the statement "I provide food for our family" had the highest rating with a mean rating of 4.72, described as always, while the least was the 
statement "I allow them to do household chores even in school days" with a mean of 2.24, described as seldom, the overall mean is 3.70 which is described as often. The results imply that parents can provide the needs of the family and support the school needs of their children.

Table 8. Educational Challenges Encountered by Parents in terms of Socio-economic Factor

\begin{tabular}{lcc}
\hline \multicolumn{1}{c}{ Statement } & Mean Rating & Descriptive Rating \\
\hline Provide their school needs & 4.58 & Always \\
Received financial assistance for education from government & 4.00 & Often \\
Received financial assistance from our tribe. & 2.60 & Occasionally \\
Provide for our family. & 4.72 & Always \\
Provide safe home environment. & 4.23 & Often \\
Allow them to do household chores even in school days & 2.24 & Seldom \\
Help them to be good in reading and writing. & 4.09 & Often \\
Correct their mistakes by explaining and telling the best things to do. & 4.46 & Often \\
We both have works. & 3.58 & Often \\
Encountered discriminations in finding job. & 2.51 & Occasionally \\
$\quad$ Overall Mean & $\mathbf{3 . 7 0}$ & Often \\
\hline
\end{tabular}

\subsection{Educational challenges Encountered by the learners in terms of Learner Factor}

As perceived by the learners, in terms of learner factor, the statement I am motivated to finish my study" had the highest rating with a mean of 4.79 , described as always, while the lowest rating was the statement "I find it hard to understand our lesson" with a mean of 2.46, described as occasionally, the overall mean is 3.97 which is described as often (see Table 9).The results imply that learners are studying to develop themselves and improve their future. They are also motivated to go to school.

Table 9. Educational Challenges Encountered by Students in terms of Learners Factor

\begin{tabular}{lcc}
\hline \multicolumn{1}{c}{ Statement } & Mean Rating & Descriptive Rating \\
\hline I am encouraged to go school every day & 4.67 & Always \\
I am motivated to study to receive awards from my parents & 2.75 & Occasionally \\
I find it hard to understand our lesson & 2.46 & Seldom \\
I can easily remember our past lesson & 3.63 & Often \\
I study hard to improve myself personally and improve my life & 4.75 & Always \\
I prefer to study my lesson than going out with my peers & 4.09 & Often \\
I still want to go to school even without money "baon" & 4.40 & Often \\
I can comprehend instructions easily & 3.96 & Often \\
I can exhibit excellence even without motivation & 4.18 & Often \\
I motivated to finish my study & 4.79 & Always \\
$\quad$ Overall Mean & $\mathbf{3 . 9 7}$ & Often \\
\hline
\end{tabular}

\subsection{Educational challenges Encountered by the learners in terms of Family Factor (Table 5.8)}

As perceived by the learners in terms of family factor, the statement "my parents correct my mistakes by explaining and telling the best things to do" had the highest rating with a mean of 4.47, described as often, while the least was the statement "my father/mother take good care of me alone" with a mean of 1.19 , describe as never, the overall mean is 2.70 which is described as occasionally.

Table 10. Educational Challenges Encountered by Students in terms of Family Factor

\begin{tabular}{|c|c|c|}
\hline Statement & $\begin{array}{l}\text { Mean } \\
\text { Rating }\end{array}$ & $\begin{array}{c}\text { Descriptive } \\
\text { Rating }\end{array}$ \\
\hline My parents help me in doing my school projects & 3.00 & Occasionally \\
\hline My parents punish me when I commit mistakes despite of difficulties & 2.16 & Seldom \\
\hline My parents encourage me to go to school every day & 4.25 & Often \\
\hline My parents let me help in working to earn money for family expenses & 2.30 & Seldom \\
\hline My parents encourage me to study my lesson after school & 3.91 & Often \\
\hline My parents correct my mistakes by explaining and telling the best things to do & 4.47 & Often \\
\hline My parents explain that we do not have permanent home & 2.21 & Seldom \\
\hline My father/mother take good care of me alone & 1.19 & Never \\
\hline Overall Mean & 2.70 & Occasionally \\
\hline
\end{tabular}


The results (see Table 10) imply that parents have limited influence over the child's peer relationships, direct parental influence remains an opportunity to leverage those factors for the benefit of the child, including their academic achievement. In line with the study conducted by Singh, and Eilam, for the self-concept of the student, family and parental support has significant impact. The parents itself should have the initiative to support the children. It is also said that dominantly, some parents are illiterate and economically depressed.

\subsection{Educational challenges Encountered by the learners in terms of Health Factor}

As perceived by the learner in terms of health factor (Table 11), the statement "we ate meals three times a day" had the highest rating with a mean of 4.65, described as always; while the least was the statement "I have vices like smoking cigarette and drinking liquor", with a mean of 1.00, described as never, the overall mean of 2.85 which is described as occasionally. The results imply that even when life is hard, parents are still trying to meet the family's need, especially their food and give value to the health of the family.

Table 11. Educational Challenges Encountered by Students in terms of Health Factor

\begin{tabular}{lcc}
\hline \multicolumn{1}{c}{ Statement } & Mean Rating & Descriptive Rating \\
\hline We are brought to the hospital when we are sick. & 3.56 & Often \\
Nutritious and healthy foods are prepared at home. & 4.42 & Often \\
Have clean hygiene facilities. & 4.56 & Always \\
Have vices like smoking cigarette and drinking liquor & 1.00 & Never \\
We ate meals three times a day & 4.65 & Always \\
I belong to those malnourished learner & 1.37 & Never \\
My parents have vices like smoking cigarette and drinking liquor & 1.40 & Never \\
We have our own comfort room & 4.42 & Often \\
I have health problem & 1.42 & Never \\
Poor housing sanitation $\quad$ Overall Mean & 1.72 & Seldom \\
& $\mathbf{2 . 8 5}$ & Occasionally \\
\hline
\end{tabular}

\subsection{Educational challenges Encountered by the learners in terms of Cultural Factor}

As perceived by the learners in terms of cultural factor (Table 12), the statement "obey and respect oral laws of the elder" had the highest rating with the mean of 4.88 , described as always, while the least was the statement "wear tribal clothes" with a mean of 2.79. described as occasionally, the overall mean is 4.11 which is described as often. The results imply that indigenous learners still obey and respect their oral laws and still proud to their culture and their tribe even in modern times.

Table 12. Educational Challenges Encountered by Students in terms of Cultural Factor

\begin{tabular}{|c|c|c|}
\hline Statement & Mean Rating & Descriptive Rating \\
\hline I am proud to use our native language & 4.42 & Often \\
\hline I am proud to say that I belong to our tribe & 4.86 & Always \\
\hline I join in the school activity showing our tradition & 4.44 & Often \\
\hline My beliefs and traditions are respected in our school & 4.58 & Always \\
\hline Our teacher uses indigenized teaching materials & 2.91 & Occasionally \\
\hline I heard stories about our tribe as told by my parents & 4.07 & Often \\
\hline My parents teach us our beliefs and traditions & 4.37 & Often \\
\hline I still observe and join in the ritual in our tribe & 3.79 & Often \\
\hline I wear tribal clothes in the public & 2.79 & Occasionally \\
\hline I obey and respect oral laws of the elders & 4.88 & Always \\
\hline Overall Mean & 4.11 & Often \\
\hline
\end{tabular}

\subsection{Educational challenges Encountered by the learners in terms of school Factor}

As perceived by the learners in terms of school factor (Table 13), the statement "individual differences are respected" had the highest rating with a mean of 4.82 , described as always, while the least was the statement "my teacher uses our native language in teaching" with a mean of 1.00, described as never, the overall mean is 3.85 which is described as often. The results imply that school respect the individual differences of the learners and value their culture and belief. The results supported by Lynch that a primary goal of culturally responsive education is to help all students become respectful of the multitudes of cultures and people that they will interact with once they exit the educational setting. This can be a daunting task for the educator, given that the world at large is infinitely more complex and diverse than the microcosmic environment that the student inhabits. 
Table 13. Educational Challenges Encountered by Students in terms of School Factor

\begin{tabular}{lcc}
\multicolumn{1}{c}{ Statement } & Mean Rating & Descriptive Rating \\
\hline My teacher uses our native language in teaching & 1.00 & Never \\
My teacher uses indigenized materials in teaching & 2.82 & Occasionally \\
My teachers treat me as a unique individual & 3.82 & Often \\
Individual differences are respected & 4.82 & Always \\
Teachers value our beliefs and traditions & 4.67 & Always \\
Our school is free from racial discrimination & 4.58 & Always \\
The school respects our culture & 4.63 & Always \\
The school innovates program that help us to sustain our progress & 4.70 & Always \\
Teachers are friendly and supportive & 4.49 & Often \\
I find it hard to understand our lesson due to lack of supportive materials & 2.95 & Occasionally \\
$\quad$ Overall Mean & $\mathbf{3 . 8 5}$ & Often \\
\hline
\end{tabular}

\subsection{Educational challenges Encountered by the learners in terms of Socio-economic Factor}

As perceived by the learners in terms of socio-economic factor (in Table 14), the statement "correct my mistakes by explaining and telling the best things to do" had the highest rating with a mean of 4.74, described as always, while the least was the statement "my parents encountered discrimination in finding job" with a mean of 2.28, described as seldom, the overall mean is 3.68 which is described as often. The results imply that learners are disciplined by their parents in order them to be corrected. They are disciplined to teach what is right and wrong.

Table 14. Educational Challenges Encountered by Students in terms of Socio-economic Factor

\begin{tabular}{lcc}
\hline \multicolumn{1}{c}{ Statement } & Mean Rating & Descriptive Rating \\
\hline They provide my school needs & 4.00 & Often \\
Received financial assistance for my education from the government & 4.30 & Often \\
Received financial assistance from our tribe & 3.70 & Often \\
Provide food for our family & 3.39 & Occasionally \\
Provide safe home environment & 4.51 & Always \\
Allow us to do household chores even school days & 2.28 & Seldom \\
Help me to be good in reading and writing & 3.98 & Often \\
Correct my mistakes by explaining and telling the best things to do & 4.74 & Always \\
They have both works & 3.58 & Often \\
They encountered discrimination in finding job & 2.28 & Seldom \\
\multicolumn{1}{r}{ Overall Mean } & $\mathbf{3 . 6 8}$ & Often
\end{tabular}

\subsection{Summary of educational challenges encountered by the parents and learners}

Summary of educational challenges encountered by the parents and learners can be seen from the table 15 that according to the parent respondents, cultural factor had the highest rating as challenges encountered with a mean of 4.19, described as often, followed by school factor with a mean of 3.97, described as often, learner factor with a mean rating of 3.90, described as often, socio-economic factor with a mean rating of 3.70 , described as often. Health factor with a mean rating of 2.90 , described as often. Meanwhile, family factor had lowest rating with a mean of 2.73 , described as occasionally.

Table 15. Educational Challenges Encountered by Parents and Learners

\begin{tabular}{cccc}
\hline Educational Challenges & \multicolumn{2}{c}{ Overall Mean Rating } & Descriptive Rating \\
& Parents & Learners & Often \\
Learner factor & 3.90 & 3.97 & Occasionally \\
Family Factor & 2.73 & 2.70 & Occasionally \\
Health Factor & 2.90 & 2.85 & Often \\
Cultural Factor & 4.19 & 4.11 & Often \\
School Factor & 3.97 & 3.85 & Often \\
\hline
\end{tabular}

The learners agree with the parents that cultural factor had the highest rating as challenges encountered with a mean rating of 4.11, described as often, followed by learner factor with a mean rating of 3.97, described as often, school factor with a mean rating of 3.85, described as often, socioeconomic factor with a mean rating of 3.68, described as often, health factor with a mean rating of 2.895 , described as often, while the family factor had the least rating with a mean of 2.70, described as occasionally. In terms with academic achievement, it is one outcome for which cumulative impact 
of a range family factors is crucial to good results. The ways in which a home environment promotes respect and enthusiasm for learning, along with the quality of the surrounding neighborhood and available school option all influence educational secondary school to work or further learning.

\subsection{Relationship between the Parent's profile and the career Choices of the learners}

The hypothesis that there is no relationship between the parents' profile and the career choices of the learners were tested using Chi-square test of independence through Megastat program in the computer (see Table 16). As shown in table 6, all the profile characteristics were not significantly related to the career choices as revealed by the p-values which are all greater than .05 level of significance. This implies that the data is not sufficient to claim that the career choices of the learners is dependent on their parents' profile. Borchert defined Career choice and selection is one of many important choices' students will make in determining their future and this decision will impact them throughout their lives. The results deviate to the study of Jungen he notes that while perception suggests career choice is an individual decision, research indicates a variety of influences are likely to determine one's ultimate career choice. Parents have been found to greatly impact the career selection process of their children.

Table 16. Relationship between the Parents' Profile and the Career Choices of the learners

\begin{tabular}{ccccc} 
Profile Characteristics & $\begin{array}{c}\text { Chi-Square } \\
\text { Value }\end{array}$ & $\begin{array}{c}\text { Degree of } \\
\text { Freedom }\end{array}$ & p-value & Decision \\
\hline Age & 21.26 & 15 & .1287 & Accept \\
HEA & 14.22 & 15 & .5091 & Accept \\
Occupation & 15.32 & 20 & .7581 & Accept \\
Monthly Income & 6.45 & 10 & .7759 & Accept \\
Ethnicity & 5.74 & 5 & .3323 & Accept \\
Number of Children & 7.45 & 10 & .6822 & Accept \\
CCT recipient & 1.99 & 5 & .8503 & Accept \\
\hline
\end{tabular}

\subsection{Relationship Between Parent-Respondents Profile and Career Aspirations of the Learners}

The hypothesis that there is no relationship between the parents' profile characteristics and the career aspirations of the learners were tested using SPSS program of the computer (see Table 17). Since multiple responses by the respondents were observed, the cross tabulation and analysis of data were done per item in the career aspiration variable. The correlation between parents' age and career aspirations of the learners, all items in career aspirations were not related to age except item 7 which is "improved living condition". This implies that parents, particularly those whose age bracket is between 40 to 49 were aspiring that their living condition will be improved through their children's educational achievement in the future. In terms in parents' occupation is not significantly related to all the items in career aspirations of the learners as indicated in the $p-$ values which are all greater than .05 level of significance. This implies that the data gathered is not sufficient to claim that the career aspirations of the indigenous learners is dependent on their parents' occupation.

This finding differs to the study of William that the parents' occupations almost always influence the careers their children will take up in the future. This is best captured by who noted; thus, It's no surprise that many people are the third or fourth generations of their families to work in the same profession. They have an insider's glimpse into their parents' occupations, making it easier for them to break into the industry. If their parents' jobs give them great satisfaction or provide a comfortable lifestyle, children see the perks early on, and may favor these careers over others. In contrast, if parents complain about their jobs or struggle to support the family on the income their jobs provide, children are more likely to seek more fulfilling or higher-paid roles. It is shown also that the parents' monthly income is not significantly related to all the items in career aspirations of the learners as indicated in the $\mathrm{p}-$ values which are all greater than .05 level of significance.This implies that the data gathered is not sufficient to claim that the career aspirations of the indigenous learners is dependent on their parents' monthly income. Moreover, only item "take vocational course" of career aspiration is dependent on the parents' ethnicity as revealed by the $\mathrm{p}$ - value of .014 which is less than .05 level of significance.

In Addition, parents' number of children is not significantly related to all the items in career aspirations of the learners as indicated in the $p$ - values which are all greater than .05 level of 
significance. This implies that the data gathered is not sufficient to claim that the career aspirations of the indigenous learners is dependent on their parents' number of children.

Table 17. Relationship Between Parent -Responden Profile and Career Aspirations of The Learners

\begin{tabular}{|c|c|c|c|c|}
\hline Profile Characteristics & Career Aspirations & Chi-square Value & p - value & Decision \\
\hline \multirow[t]{6}{*}{ Age } & Finished High School & .965 & .810 & Accept \\
\hline & Finished College & 1.535 & .674 & Accept \\
\hline & Take vocational course & 1.852 & .604 & Accept \\
\hline & Look for a job after HS & 3.774 & .287 & Accept \\
\hline & Help us in livelihood & 4.487 & .213 & Accept \\
\hline & Improve living condition & 8.966 & .030 & Reject \\
\hline \multirow[t]{6}{*}{ Educational Attainment } & Finished High School & 5.608 & .132 & Accept \\
\hline & Finished College & 2.471 & .480 & Accept \\
\hline & Take vocational course & 1.501 & .682 & Accept \\
\hline & Look for a job after HS & 1.265 & .738 & Accept \\
\hline & Help us in livelihood & 7.281 & .063 & Accept \\
\hline & Improve living condition & 7.739 & .052 & Accept \\
\hline \multirow[t]{6}{*}{ Occupation } & Finished High School & 3.481 & .175 & Accept \\
\hline & Finished College & 1.899 & .387 & Accept \\
\hline & Take vocational course & .269 & .874 & Accept \\
\hline & Look for a job after HS & 5.949 & .051 & Accept \\
\hline & Help us in livelihood & .487 & .816 & Accept \\
\hline & Improve living condition & 1.067 & .587 & Accept \\
\hline \multirow[t]{6}{*}{ Monthly Income } & Finished High School & .573 & .751 & Accept \\
\hline & Finished College & 1.865 & .393 & Accept \\
\hline & Take vocational course & .341 & .843 & Accept \\
\hline & Look for a job after HS & .534 & .766 & Accept \\
\hline & Help us in livelihood & 5.855 & .054 & Accept \\
\hline & Improve living condition & 4.930 & .085 & Accept \\
\hline \multirow[t]{6}{*}{ Ethnicity } & Finished High School & .143 & .706 & Accept \\
\hline & Finished College & .032 & .859 & Accept \\
\hline & Take vocational course & 6.021 & .014 & Reject \\
\hline & Look for a job after HS & 1.373 & .242 & Accept \\
\hline & Help us in livelihood & .127 & .722 & Accept \\
\hline & Improve living condition & .000 & .985 & Accept \\
\hline \multirow[t]{6}{*}{ Number of Children } & Finished High School & .000 & 1.000 & Accept \\
\hline & Finished College & .463 & .793 & Accept \\
\hline & Take vocational course & 1.545 & .462 & Accept \\
\hline & Look for a job after HS & 1.126 & .570 & Accept \\
\hline & Help us in livelihood & .548 & .760 & Accept \\
\hline & Improve living condition & .307 & .858 & Accept \\
\hline \multirow[t]{6}{*}{ CCT Recipient } & Finished High School & .911 & .340 & Accept \\
\hline & Finished College & 3.463 & .080 & Accept \\
\hline & Take vocational course & .583 & .445 & Accept \\
\hline & Look for a job after HS & 2.299 & .129 & Accept \\
\hline & Help us in livelihood & .388 & .533 & Accept \\
\hline & Improve living condition & 1.083 & .298 & Accept \\
\hline
\end{tabular}

Further, the parents' CCT recipient is not significantly related to all the items in career aspirations of the learners as indicated in the $\mathrm{p}$ - values which are all greater than .05 level of significance. This implies that the data gathered is not sufficient to claim that the career aspirations of the indigenous learners is dependent on their parents' CCT recipient. 


\subsection{Relationship Between Learner-Respondents Profile and their Career Aspirations (Table 6c)}

The relationship between the learners' profile and their career aspirations were cross tabulated and analysed through SPSS using Chi-square test of independence (Table 18). As shown in the table in terms of age profile the item "Look for a job after High School" with coefficient of 6.687 with a pvalue of .035 , in terms of sex profile item "Take vocational course" with coefficient 8.482 with pvalue of .004 , in terms of track profile, items "finished high school", "help us in livelihood", and "improve living condition" with coefficients of 5.429, 8.292, and 11.811 with p-values of .020, .004, and .001 respectively and item "take vocational course" with coefficient of 6.021 and p-value .014 are dependent on learners' profile which are all less than .05 level of significance.

Table 18. Relationship Between Learner-Respondents Profile and Their Career

\begin{tabular}{|c|c|c|c|c|}
\hline Profile Characteristics & Career Aspirations & Chi-square Value & p-value & Decision \\
\hline \multirow[t]{6}{*}{ Age } & Finished High School & 1.458 & .482 & Accept \\
\hline & Finished College & 623 & .732 & Accept \\
\hline & Take vocational course & 1.852 & .396 & Accept \\
\hline & Look for a job after HS & 6.687 & .035 & Reject \\
\hline & Help us in livelihood & 5.354 & .069 & Accept \\
\hline & Improve living condition & 5.405 & .067 & Accept \\
\hline \multirow[t]{6}{*}{ Sex } & Finished High School & 1.357 & .244 & Accept \\
\hline & Finished College & .154 & .695 & Accept \\
\hline & Take vocational course & 8.482 & .004 & Reject \\
\hline & Look for a job after HS & .929 & .335 & Accept \\
\hline & Help us in livelihood & .004 & .953 & Accept \\
\hline & Improve living condition & .191 & .662 & Accept \\
\hline \multirow[t]{6}{*}{ Track } & Finished High School & 5.429 & .020 & Reject \\
\hline & Finished College & .154 & .695 & Accept \\
\hline & Take vocational course & 1.357 & .244 & Accept \\
\hline & Look for a job after HS & 2.417 & .120 & Accept \\
\hline & Help us in livelihood & 8.292 & .004 & Reject \\
\hline & Improve living condition & 11.811 & .001 & Reject \\
\hline \multirow[t]{6}{*}{ Ethnicity } & Finished High School & .143 & .706 & Accept \\
\hline & Finished College & .032 & .859 & Accept \\
\hline & Take vocational course & 6.021 & .014 & Reject \\
\hline & Look for a job after HS & 1.184 & .227 & Accept \\
\hline & Help us in livelihood & .127 & .722 & Accept \\
\hline & Improve living condition & .000 & .985 & Accept \\
\hline \multirow[t]{6}{*}{ Birth Order } & Finished High School & .944 & .624 & Accept \\
\hline & Finished College & .881 & .644 & Accept \\
\hline & Take vocational course & .927 & .629 & Accept \\
\hline & Look for a job after HS & 1.139 & .566 & Accept \\
\hline & Help us in livelihood & .309 & .857 & Accept \\
\hline & Improve living condition & .736 & .692 & Accept \\
\hline \multirow[t]{6}{*}{ Distance of Residence } & Finished High School & .570 & .752 & Accept \\
\hline & Finished College & 2.653 & .265 & Accept \\
\hline & Take vocational course & 2.393 & .302 & Accept \\
\hline & Look for a job after HS & 1.462 & .483 & Accept \\
\hline & Help us in livelihood & 1.735 & .420 & Accept \\
\hline & Improve living condition & 2.031 & .362 & Accept \\
\hline
\end{tabular}

This manifest that in terms of age, the learners were not aiming to look for a job after they graduated in senior high school, as such, they are hesitant to continue their studies in college and in terms of sex, male learners are willing to take vocational course than the female learners and learners who preferred TVL track were aiming to finish high school, help their parents in livelihood, and as such, improve their living condition and in terms of ethnicity indigenous learners are showing less priorities on taking vocational course since their first priority is to go to college after finishing high school. According to the study of Anttalainen he stated that vocational education often follows the gen- der-segregated patterns of the labor force [17]. Girls choose service and care branches; boys go for technical and vocational schools. This division has remained almost unchanged for the last 40 years and is clearest at the lowest levels of vocational education. Male students continue their post-comprehensive studies in vocational institutions, whereas female students go to the general upper secondary schools. While 
in terms of birth order and distance of residence were all independent in all item in career aspirations. This implies that the data is not sufficient to claim that career aspirations is dependent on the birth order and distance of residence of the indigenous learners.

\subsection{Relationship between the demographic profile of the parents and the educational challenges}

Testing the significant of relationship between the parent's demographic profile and the educational challenges encountered, parent's occupation, cash conditional transfer recipient, number of children, did significantly correlate to the educational challenges as evidenced by their $p$ - value which are all less than .01 level of significance.

Table 19. Relationship between the demographic profile of the parents and the educational challenges encountered

\begin{tabular}{|c|c|c|c|}
\hline Profile Characteristics & Pearson $\mathbf{r}$ & p - value & Decision \\
\hline \multicolumn{4}{|l|}{ Learners Factor } \\
\hline Age & .166 & .218 & Accept \\
\hline Highest Educational Attainment & -.075 & .580 & Accept \\
\hline Occupation & $-.346^{* *}$ & .008 & Reject \\
\hline Monthly Income & -.012 & .931 & Accept \\
\hline Ethnicity & -.119 & .377 & Accept \\
\hline Number of Children & -.039 & .775 & Accept \\
\hline CCT Recipient & -.122 & .366 & Accept \\
\hline \multicolumn{4}{|l|}{ Family factor } \\
\hline Age & .052 & .698 & Accept \\
\hline Highest Educational Attainment & .024 & .857 & Accept \\
\hline Occupation & -.037 & .783 & Accept \\
\hline Monthly Income & -.066 & .626 & Accept \\
\hline Ethnicity & .204 & .129 & Accept \\
\hline Number of Children & .018 & .897 & Accept \\
\hline CCT Recipient & $.268 *$ & .044 & Reject \\
\hline Age & -.178 & .186 & Accept \\
\hline Highest Educational Attainment & .074 & .584 & Accept \\
\hline Occupation & -.070 & 603 & Accept \\
\hline Monthly Income & .001 & .993 & Accept \\
\hline Ethnicity & -.219 & .101 & Accept \\
\hline Number of Children & $-.287 *$ & .031 & Reject \\
\hline CCT Recipient & -.059 & .663 & Accept \\
\hline \multicolumn{4}{|l|}{ Cultural Factor } \\
\hline Age & .006 & .964 & Accept \\
\hline Highest Educational Attainment & -.125 & .353 & Accept \\
\hline Occupation & .138 & .307 & Accept \\
\hline Monthly Income & -.119 & .379 & Accept \\
\hline Ethnicity & -.202 & .131 & Accept \\
\hline Number of Children & -.019 & .887 & Accept \\
\hline CCT Recipient & .169 & .209 & Accept \\
\hline \multicolumn{4}{|l|}{ School Factor } \\
\hline Age & -.015 & .912 & Accept \\
\hline Highest Educational Attainment & -.144 & .285 & Accept \\
\hline Occupation & $-.279 *$ & .036 & Reject \\
\hline Monthly Income & -.025 & .855 & Accept \\
\hline Ethnicity & .084 & .532 & Accept \\
\hline Number of Children & -.079 & .559 & Accept \\
\hline CCT Recipient & -.041 & .760 & Accept \\
\hline \multicolumn{4}{|l|}{ Socio-Economic Factor } \\
\hline Age & -.080 & .555 & Accept \\
\hline Highest Educational Attainment & .108 & .424 & Accept \\
\hline Occupation & .248 & .063 & Accept \\
\hline Monthly Income & -.247 & .065 & Accept \\
\hline Ethnicity & -.201 & .134 & Accept \\
\hline Number of Children & .072 & .596 & Accept \\
\hline CCT Recipient & $.296^{*}$ & .026 & Reject \\
\hline
\end{tabular}

The rest of the profile variables were not significantly correlated to the other educational challenges as evidenced by their $\mathrm{p}-$ values which are all greater than .01 level. The results imply that parents 
whose occupation are labourer, farmer, driver, non CCT recipient and with many children indicate high level of educational challenges (see Table 19). Haveman indicated that parents with higher educational level could motivate the intellectual potential within their children that may lead them to perform better in school and in return further their education [18].

\subsection{Relationship between the demographic profile of the learner and the educational challenges}

Thus, educated parents were also found to be able to make constructive decisions, such as how much time to spend with their children, give their income and may decide on how much to give to their children's education.

Table 20. Relationship between the demographic profile of the learner and the educational challenges encountered

\begin{tabular}{|c|c|c|c|}
\hline Profile Characteristics & Pearson $\mathbf{r}$ & p-value & Decision \\
\hline \multicolumn{4}{|l|}{ Learners Factor } \\
\hline Age & .145 & .280 & Accept \\
\hline Sex & -.049 & .717 & Accept \\
\hline Grade Level & - & - & Correlation failed ${ }^{\mathrm{k}}$ \\
\hline Track & .153 & .256 & Accept \\
\hline Ethnicity & -.119 & .377 & Accept \\
\hline Birth Order & .062 & .649 & Accept \\
\hline Distance from school & $.362 * *$ & .006 & Reject \\
\hline \multicolumn{4}{|l|}{ Family Factor } \\
\hline Age & .114 & .397 & Accept \\
\hline Sex & -.219 & .101 & Accept \\
\hline Grade Level & - & - & Correlation failed $^{\mathrm{k}}$ \\
\hline Track & .145 & .282 & Accept \\
\hline Ethnicity & .204 & .129 & Accept \\
\hline Birth Order & -.017 & .900 & Accept \\
\hline Distance from school & .165 & .221 & Accept \\
\hline \multicolumn{4}{|l|}{ Health Factor } \\
\hline Age & .082 & .545 & Accept \\
\hline Sex & -.091 & .501 & Accept \\
\hline Grade Level & - & - & Correlation failed ${ }^{\mathrm{k}}$ \\
\hline Track & -.031 & .819 & Accept \\
\hline Ethnicity & -.219 & .101 & Accept \\
\hline Birth Order & $-.405 * *$ & .002 & Reject \\
\hline Distance from school & $.310 *$ & .019 & Reject \\
\hline \multicolumn{4}{|l|}{ Cultural Factor } \\
\hline Age & -.035 & .795 & Accept \\
\hline Sex & -.121 & .368 & Accept \\
\hline Grade Level & - & - & Correlation failed $^{\mathrm{k}}$ \\
\hline Track & -.159 & .238 & Accept \\
\hline Ethnicity & -.202 & .131 & Accept \\
\hline Distance from school & .194 & .148 & Accept \\
\hline \multicolumn{4}{|l|}{ School Factor } \\
\hline Age & .161 & .795 & Accept \\
\hline Sex & -.095 & .480 & Accept \\
\hline Grade Level & - & - & Correlation failed ${ }^{\mathrm{k}}$ \\
\hline Track & .122 & .365 & Accept \\
\hline Ethnicity & .084 & .532 & Accept \\
\hline Birth Order & -.009 & .947 & Accept \\
\hline Distance from school & .075 & .578 & Accept \\
\hline \multicolumn{4}{|l|}{ Socio-economic Factor } \\
\hline Age & .024 & .858 & Accept \\
\hline Sex & $-.274 *$ & .039 & Reject \\
\hline Grade Level & - & - & Correlation failed ${ }^{\mathrm{k}}$ \\
\hline Track & .046 & .732 & Accept \\
\hline Ethnicity & -.201 & .134 & Accept \\
\hline Birth Order & -.105 & .438 & Accept \\
\hline Distance from school & $.290^{*}$ & .028 & Reject \\
\hline
\end{tabular}

Legend: kcorrelation failed due to homogenous data (there is only one grade level) ***orrelation is significant at 0.01 level *correlation is significant at 0.05 level 
And it also supported by Gouxet that family size has effects on quality of life. These include health, nutrition, educational attainment of children, social status of families as well as their ability to adequately cater for the needs of their families [19].A family size of five including parents is considered sizeable. Such a family can cater for the needs of its members. Sizeable family is likely to enjoy the comfort of life with the choice to afford and enjoy identifiable luxuries of life. Further, this finding was like the study of Usaini to him, occupational status reflects the educational attainment required to obtain a job and income levels [20]. When parents have a better occupation, they make adequate provision for their children education [21], [22]. They provide economic, social, psychological, and emotional support to their children, and this would make it possible for the children to perform well in their educational attainment [23], [24].

Testing the significant relationship (Table 20) between the learner's demographic profile and the educational challenges encountered; distance from school, birth order and sex did significantly correlate to the educational challenges as evident by their $p$ - value of which are all less than .01 level of significance, the rest of the profile variables were not significantly correlated to the other variable (educational challenges) as evident by their $\mathrm{p}$ - values which are greater than .01 level.

Table 21. Difference Between Career Aspirations Among Parents and Learners

\begin{tabular}{ccccccc}
\hline Source of Variation & $\begin{array}{c}\text { Sum of } \\
\text { Squares }\end{array}$ & $\begin{array}{c}\text { Degree of } \\
\text { Freedom }\end{array}$ & $\begin{array}{c}\text { Mean } \\
\text { Squares }\end{array}$ & F Value & $\begin{array}{c}\text { Critical } \\
\text { Value }\end{array}$ & Decision \\
\hline Between rows & 320.3 & 1 & 320.3 & 28.26 & 6.607 & Reject \\
Within column & 2389.7 & 5 & 477.9 & 42.17 & 5.050 & \\
Error & 56.7 & 5 & 11.3 & & & \\
Total & 2766.7 & 11 & & & & \\
\hline
\end{tabular}

The results implied that indigenous learners whose residence measuring $5 \mathrm{~km}$ and above and first child (eldest) learners indicate high level of educational challenges compared to those other learners. This finding was like the study of Galabawa in his study which he conducted to and using and revealed that, when schools are located far distance from home, academic performance of learners is affected, as most of them remain with little time to concentrate on their 15 (private or in school) studies due to the long distances they travel to reach their schools [25]. The difference between parents and learners career choices, aspirations and educational challenges were processed and analysed using Two-Way Analysis of Variance and t-test through Microsoft excel program in the computer. In Table 21, the F - value of 28.26 is greater than the critical value of 6.607, thus, the null hypothesis that there is no significant difference between career aspirations among learners and their parents is rejected.

Table 22. Difference Between Career Choice Among Parents and Learners

\begin{tabular}{ccccccc}
\hline Source of Variation & $\begin{array}{c}\text { Sum of } \\
\text { Squares }\end{array}$ & $\begin{array}{c}\text { Degree of } \\
\text { Freedom }\end{array}$ & $\begin{array}{c}\text { Mean } \\
\text { Squares }\end{array}$ & F Value & $\begin{array}{c}\text { Critical } \\
\text { Value }\end{array}$ & Decision \\
\hline Between rows & 3 & 1 & 320.3 & 0.136 & 6.608 & Accept \\
Within column & 452 & 5 & 477.9 & 4.109 & 5.050 & Accept \\
Error & 110 & 5 & 11.3 & 2.2 & & \\
Total & 565 & 11 & & & & \\
\hline
\end{tabular}

This implies that learners were not influenced by their parents in their career aspirations. As shown in Table 22, there is no significant difference between the career choice among indigenous learners and their parents as evident by the F-value of 0.136 which is less than the critical value of 6.608 . This implies that the indigenous learners and their parents were having a mutual understanding about the career choice of the learners.

Table 23. Difference between educational challenges among learners and parents

\begin{tabular}{ccccc}
\hline Factor & Degree of Freedom & t - value & p - value & Decision \\
\hline Learners Factor & 56 & 1.058 & .295 & .684 \\
Family Factor & 56 & 0.409 & .319 & $\mathrm{Accept}$ \\
Health Factor & 56 & 1.005 & .343 & $\mathrm{Accept}$ \\
Cultural Factor & 56 & 0.955 & .056 & $\mathrm{Accept}$ \\
Social Factor & 56 & 1.952 & .747 & $\mathrm{Accept}$ \\
Socio-economic & 56 & 0.324 & $\mathrm{Accept}$ \\
\hline
\end{tabular}


As shown in Table 23, there is no significant difference between educational challenges among learners and parents in all factors as revealed by p-values which are all greater than .05 level of significance. This implies that the learners and their parents encountered the same level of educational challenges.

\section{Conclusion}

Based on the findings, the following conclusions: (1) Most of the parent respondents were aged 39-44, female, high school level, farming was the primary occupation, earned below 1,000, Palawan, with 3-4 number of children and cash conditional recipient; (2) Majority of the learner respondents were aged 18-19 years old, female, grade 12 students, enrolled in Technical Vocational and Livelihood, Palawan, 1st child, and travelled more than 5 kilometers distance of home to school; (3) Parents' aspirations for their children are to finish their study and to find a stable job for them to help their family and the same response with the learner respondents for their career aspiration; (4) Parents and learners were having a mutual understanding about the career choice of the learners; (5) There is no significant relationship between the parent's profile and the career choices of the learners; (6) There is no significant relationship between parent-respondents profile and career aspirations of the learners except in parents age; (7) There is no significant relationship between learner-respondents profile and their career aspirations except in age, sex and track profile; (8) There is no significant relationship between the demographic profile of the parents and the educational challenges except in parents' occupation, cash conditional transfer recipient and number of children; (9) There is no significant relationship between the demographic profile of the learners and the educational challenges except in distance from school, birth order and sex; (10) There is significant difference between career aspirations among learners and their parents while there is no significant difference between the career choice among indigenous learners and their parents and educational challenges among learners and parents.

\section{Acknowledgment}

The authors would like to thank College of Education, Western Philippines University, Princesa City, Philippines, for helping with this research and the granted supports.

\section{Declarations}

Author contribution $\quad$ : ADJP: Conceptualization, methodology, writing draft; DRP: Visualization and reviewing; CMI: investigation and reviewing.

Funding statement $\quad:$ No funding statement.

Conflict of interest $\quad$ : The authors declare no conflict of interest.

Additional information : No additional information is available for this paper.

\section{References}

[1] I. Lundegård and P. Wickman, "Conflicts of interest: an indispensable element of education for sustainable development," Environ. Educ. Res., vol. 13, no. 1, pp. 1-15, Feb. 2007, doi: 10.1080/13504620601122566.

[2] D. Rose, "Culture, competence and schooling: Approaches to literacy teaching in indigenous school education," Pedagog. Shap. Conscious. Linguist. Soc. Process., pp. 217-245, 1999, available at: Google Scholar.

[3] G. Magni, "Indigenous knowledge and implications for the sustainable development agenda," Eur. $J$. Educ., vol. 52, no. 4, pp. 437-447, Dec. 2017, doi: 10.1111/ejed.12238.

[4] G. Cosentino, "Tribal Politics: The Disruptive Effects of Social Media in the Global South," in Social Media and the Post-Truth World Order, Cham: Springer International Publishing, 2020, pp. 113-133, doi: 10.1007/978-3-030-43005-4_5.

[5] L. Garcia-Alix, "The United Nations permanent forum on indigenous issues discusses climate change," Indig. Aff., vol. 2, pp. 1-23, 2008, available at: Google Scholar.

[6] I. Abu-Saad and D. Champagne, Indigenous education and empowerment: International perspectives, vol. 17. Rowman Altamira, 2006, available at: Google Scholar. 
[7] C. Chamberlain, D. Fergie, A. Sinclair, and C. Asmar, "Traditional midwifery or 'wise women'models of leadership: Learning from Indigenous cultures: '... Lead so the mother is helped, yet still free and in charge...'Lao Tzu, 5th century BC," Leadership, vol. 12, no. 3, pp. 346-363, 2016, doi: $10.1177 / 1742715015608426$.

[8] D. A. Mihesuah and A. C. Wilson, Indigenizing the academy: Transforming scholarship and empowering communities. U of Nebraska Press, 2004, available at: Google Scholar.

[9] R. L. Barsh, “An Advocate's Guide to the Convention on Indigenous and Tribal Peoples," Okla. City UL Rev., vol. 15, p. 209, 1990, available at: Google Scholar.

[10] T. Joona, "International Norms and Domestic Practices in Regard to ILO Convention No. 169-with Special Reference to Articles 1 and 13-19," Int. Community Law Rev., vol. 12, no. 2, pp. 213-260, 2010, doi: 10.1163/187197310X498606.

[11] S. MAY and S. AIKMAN, "Indigenous Education: Addressing current issues and developments," Comp. Educ., vol. 39, no. 2, pp. 139-145, May 2003, doi: 10.1080/03050060302549.

[12] R. Stavenhagen, "Ethnodevelopment: A Neglected Dimension in Development Thinking (1986)," 2013, pp. 65-86, doi: 10.1007/978-3-642-34150-2_5.

[13] E. A. Young, Third world in the first: development and indigenous peoples. Psychology Press, 1995, doi: 10.4324/9780203318232.

[14] M. Battiste, Indigenous knowledge and pedagogy in First Nations education: A literature review with recommendations. National Working Group on Education Ottawa, 2002, available at: Google Scholar.

[15] R. T. Ornelas, "Implementing the Policy of the UN Declaration on the Rights of Indigenous Peoples.," Int. Indig. Policy J., vol. 5, no. 1, 2014, doi: 10.18584/iipj.2014.5.1.4.

[16] J. W. Creswell and J. D. Creswell, Research design: Qualitative, quantitative, and mixed methods approaches. Sage publications, 2017, available at: Google Scholar.

[17] H. Varsa, Shaping structural change in Finland: the role of women. Ministry of Social Affairs and Health, 1993, available at: Google Scholar.

[18] R. Haveman and B. Wolfe, "The determinants of children's attainments: A review of methods and findings," J. Econ. Lit., vol. 33, no. 4, pp. 1829-1878, 1995, available at: Google Scholar.

[19] D. Goux and E. Maurin, "The effect of overcrowded housing on children's performance at school," $J$. Public Econ., vol. 89, no. 5-6, pp. 797-819, Jun. 2005, doi: 10.1016/j.jpubeco.2004.06.005.

[20] M. I. Usaini and N. B. Abubakar, "The Impact of Parents Occupation on Academic Performance of Secondary School Students in Kuala Terengganu," Multiling. Acad. J. Educ. Soc. Sci., vol. 3, no. 1, Nov. 2015, doi: 10.6007/MAJESS/v3-i1/1899.

[21] W. H. Sewell, A. O. Haller, and G. W. Ohlendorf, "The educational and early occupational status attainment process: Replication and revision," Am. Sociol. Rev., pp. 1014-1027, 1970, doi: $10.2307 / 2093379$.

[22] J. S. Eccles, “Understanding women's educational and occupational choices: Applying the Eccles et al. model of achievement-related choices," Psychol. Women Q., vol. 18, no. 4, pp. 585-609, 1994, doi: 10.1111/j.1471-6402.1994.tb01049.x.

[23] N. E. El Nokali, H. J. Bachman, and E. Votruba-Drzal, "Parent Involvement and Children's Academic and Social Development in Elementary School," Child Dev., vol. 81, no. 3, pp. 988-1005, May 2010, doi: 10.1111/j.1467-8624.2010.01447.x.

[24] M. Roy and R. Giraldo-García, "The Role of Parental Involvement and Social/Emotional Skills in Academic Achievement: Global Perspectives.," Sch. Community J., vol. 28, no. 2, pp. 29-46, 2018, available at: Google Scholar.

[25] J. C. J. Galabawa, "Developments and issues regarding universal primary education (UPE) in Tanzania," Reach. Out, Reach. All, vol. 49, 2001, available at: Google Scholar. 